\title{
Physiological status of conifer seedlings treated with radiation, drought and frost stress mitigation techniques: a laboratory assessment
}

\author{
Santiago A. Varela ${ }^{1}$ Mariana N. Weigandt ${ }^{1,2}$. \\ Priscila Willems ${ }^{1} \cdot$ Emilio Bianchi $^{1,2}$.Juan P. Diez ${ }^{1}$. \\ Javier E. Gyenge ${ }^{2,3}$
}

Received: 13 November 2014/ Accepted: 13 May 2015/Published online: 16 May 2015

(C) Springer Science+Business Media Dordrecht 2015

\begin{abstract}
Post planting assistance techniques during early ontogeny may be a determining factor for tree survival in stressful habitats. In the eastern region of NW Patagonia, stands of the fast-growing exotic conifers Pinus ponderosa (Ponderosa pine) and Pseudotsuga menziesii (Douglas fir) are being established in places which are currently, or were in the past, occupied by native Austrocedrus chilensis (mountain cypress) forests. We hypothesize that mitigation techniques could (1) reduce photoinhibition and consequently increase the net photosynthesis rate of plants under high radiation conditions due to increases in the dissipation of radiation with Kaolin, (2) improve water availability in soils using hydrogel, and (3) reduce the effects of chills and frosts events in the species that are most susceptible to environmental stress, A. chilensis and $P$. menziesii, achieving similar values to those measured in the most resistant species, $P$. ponderosa using film-forming polymers such as Poly-1-p-Menthene. The short-term responses of seedlings to solar radiation, soil water availability and air temperature were evaluated through gas exchange capacities. Our results indicate that the effects of the different techniques depend on the susceptibility of the species to environmental stress. Kaolin treatment increased stomatal conductance, photosynthesis and transpiration rates in all species. For the hydrogel assay, higher pot volumetric water content was observed in treated plants than in control plants. Pinus ponderosa showed a lower response to the application of hydrogel, while a positive response was observed in $A$. chilensis and no effect in $P$. menziesii. The frost mitigation technique evaluated proved unsuitable for the three study species, but appears to work as an anti-desiccant for $P$. menziesii. In order to optimize the process of planting and establishment for a particular species, the package of techniques needs to be evaluated regarding the requirements and susceptibility to environmental stress of that species.
\end{abstract}

Santiago A. Varela

varela.santiago@inta.gob.ar

1 Grupo de Ecología Forestal, INTA EEA Bariloche, CC 277 (8400), San Carlos de Bariloche, Río Negro, Argentina

2 Consejo Nacional de Investigaciones Científicas y Técnicas, CONICET, Buenos Aires, Argentina

3 AER Tandil, INTA EEA Balcarce, Buenos Aires, Argentina 
Keywords Kaolin $\cdot$ Hydrogel $\cdot$ Poly-1-p-menthene $\cdot$ Seedling survival

\section{Introduction}

Given the fact that the initial life stages of trees are particularly susceptible to environmental stress conditions (Niinemets 2010; Beniwal et al. 2011), the development of stress mitigation strategies during early ontogeny seems to be a determining factor for survival in habitats with environmental stress (Pratolongo et al. 2003). In the context of Global Change, climatic forecasts predict more stressful conditions than current or historical ones for several parts of the world (IPCC 2008). Thus, the development and evaluation of postplanting techniques that contribute to the mitigation of negative effects on forest plantations should be studied and validated (Aitken et al. 2008; Oliet and Jacobs 2012).

The climate of NW Argentinean Patagonia is characterized by semi-arid conditions with marked seasonality superimposed on a spatial gradient of precipitation, with high interannual variability that also increased in the drier region (Jobbagy et al. 1995; Paruelo et al. 1998). Mean annual temperature ranges from $4{ }^{\circ} \mathrm{C}$ in the south of the region to $12{ }^{\circ} \mathrm{C}$ in the north (Paruelo et al. 1998). The absolute maximum and minimum temperatures are in the order of 34 and $-20{ }^{\circ} \mathrm{C}$ respectively. The mean maximum temperature in the region ranges from 14 to $22{ }^{\circ} \mathrm{C}$ and the mean minimum temperature ranges from 0 to $6{ }^{\circ} \mathrm{C}$ (SMN 2008). The average period of frost lasts from February to December in a narrow strip alongside the Andes, and from March to November towards the east, in the ecotone between the temperate forests and the semi-arid steppes (Burgos 1971). Climate models predict an increase in future climate variability in the Patagonian region, with a trend towards greater water stress and extreme events (Fuenzalida et al. 2006; IPCC 2008), which could jeopardize the survival of conifer seedlings of both native and introduced species.

In the eastern region of NW Patagonia, where mean annual precipitation ranges from 650 to $1200 \mathrm{~mm}$, stands of fast growing exotic conifers Ponderosa pine (Pinus ponderosa Dougl. Ex Laws.) and in a lower proportion, Douglas fir (Pseudotsuga menziesii Mirb. Franco.) are now being established at sites which are currently, or have been in the past, occupied by forests of the native mountain cypress [Austrocedrus chilensis (D. Don) Pic. Sermolli et Bizzarri]. Both $P$. ponderosa and P. menziesii are native to North America and have a wide geographical distribution range, occupying sites with variable climatic conditions (Oliver and Ryker 1990; Kavanagh et al. 1999). Both species differ in ecological niche with $P$. ponderosa living in drier sites than P. menziesii (Oliver and Ryker 1990).

Ecophysiological studies and empirical observation in NW Patagonia have shown that $P$. ponderosa seedlings have higher capacity to survive under stressful conditions than $P$. menziesii and A. chilensis (SAGPyA 1999). The synergies of atmospheric demand, high solar radiation and summer drought, plus frosts from spring until autumn are the most important stress factors in NW Patagonia. Several studies have concluded that the magnitude of the stress effect on $P$. ponderosa and its survival in hot dry sites depend primarily on its capacity for heat dissipation through rapid transpiration (DeLucia and Schlesinger 1991). Pinus ponderosa showed high capacity to survive under drought conditions by developing a deep taproot that facilitates the acquisition of soil water, but this strategy fails when drought occurs during spring (Fernández et al. 2014). Late frost and water stress are mentioned as the main sources of mortality for $P$. menziesii plantations in Patagonia (Tejera and Davel 2005). The survival of P. menziesii seedlings improved when they were 
planted under the cover of other species such as tall shrubs or trees (Tejera and Davel 2005). Shading presumably decreases atmospheric demand and/or leaf temperature, enhancing seedling survival.

Austrocedrus chilensis provides timber for construction and furniture throughout Patagonia, and is the native species with the greatest commercial importance in the region (Letourneau 2006). The A. chilensis native conifer forests occupy sites with significant water deficits, growing as isolated clumps even in the Patagonian steppe (with rainfall less than $500 \mathrm{~mm}_{\text {year }}{ }^{-1}$ ). Nevertheless, mortality episodes and/or drastic reduction of growth have occurred in association with "El Niño" periods (hot, dry summers; Villalba and Veblen 1998; Suarez et al. 2004). The natural regeneration of A. chilensis is severely limited by environmental stress. Its survival in the early stages of establishment requires nurse plants (Letourneau 2006) that will prevent high radiation levels from producing damage caused basically by the low capacity for energy dissipation due to the high hydraulic resistance of the soil-to-leaf pathway (Gyenge et al. 2007). Even when soil water availability was not limiting, all seedlings showed early stomatal closure in response to moderate evaporative demand. Excess radiation can thus cause deleterious effects on performance.

To date, there is no systematized information about seedling mortality for the different species planted in NW Patagonia. The average rates of seedling mortality are highly variable depending on the species, the climatic conditions of the year of plantation, site quality index, presence or absence of nurse species, herbivore pressure, etc. However it is important to highlight that the highest percentage of deaths occurs during the first months after planting, and that the plants can be considered safely established several years after planting (Rago pers. comm.; Aparicio 2014). In addition, the abovementioned susceptibilities of each species mean that the average seedling mortality rate tends to be higher for A.chilensis and $P$. menziesii than for $P$. ponderosa.

There are several examples of stress mitigation techniques used in fruit and tree species (e.g. clays, water retention polymers, antitranspirant, antifreeze, etc.). One example of radiation management is the use of inert mineral clays such as Kaolin $\left[\mathrm{Al}_{4} \mathrm{Si}_{4} \mathrm{O}_{10}(\mathrm{OH})_{8}\right]$ applied as a suspension to plant canopies, forming a film on leaves that increases reflection and reduces absorption of light (Cantore et al. 2009). It has been found that covering plants with Kaolin limits thermal stress (Melgarejo et al. 2004) and generates moderate water uptake (Moftah and Al-Humaid 2005), reducing damage by sunburn (Wand et al. 2006) and limiting the incidence of some pests (Knight et al. 2000).

Synthetic polymers have been used in plantation management to protect roots because of their high water retention capacity, which reduces the irrigation frequency needed and the loss of chemicals through leaching and washing (e.g. Sojka et al. 2007; Luo et al. 2009; Shi et al. 2010; Chirino et al. 2011; Savi et al. 2014).

Water emulsifier organic concentrate with Poly-1-p-Menthene as the principal active agent has been used on plants as a spreader-sticker to extend pesticides and lengthen the life of foliar-applied insecticides and fungicides. The soft, flexible film formed after the spray dries significantly reduces moisture loss through the plant foliage. Additionally, it can be used to reduce winter damage caused by cold desiccation.

The aim of this study is to evaluate the potential use of a package of techniques (kaolin in order to reduce the radiation on foliage, hydrogel in order to increase soils water availability and anti-desiccants in order to reduce the effects of frosts), to optimize the process of production, planting and establishment of forests trees with different susceptibilities to environmental stress. We hypothesize that by increasing the dissipation of radiation, improving the water availability of soils and reducing the effects of chills and 
frosts events in A. chilensis and $P$. menziesii, the implementation of mitigation techniques would increase their physiological performance, enabling them to attain values similar to those of $P$. ponderosa. As a first part of this study, we evaluate the potential of different mitigation techniques under laboratory conditions and discuss the results according to preliminary information from field assays.

\section{Materials and methods}

Greenhouse and growth chamber assays were performed under semi-controlled conditions during the growing season of October to March 2012-2013 at the Agricultural Experimental Station of the National Institute for Crop and Livestock Technology (Instituto Nacional de Tecnología Agropecuaria, INTA) Bariloche, Río Negro Province, Argentina $\left(41^{\circ} 08^{\prime} \mathrm{S}, 71^{\circ} 17^{\prime} \mathrm{W}\right)$. For the greenhouse assays, seedlings of all the three species were placed on open countertops in a completely randomized design to ensure the self-pruning of roots. The stress variables of interest (high radiation levels, low water availability and low temperatures) were generated to evaluate the effects of three mitigation techniques (see below) on the short-term responses of the seedlings. A pool of geographical origins per species and the same production technique were used for all assays. The experiments were performed on 2-year-old seedlings. One month before the beginning of the experiment, all the seedlings were transplanted from their original containers to 3-1 plastic pots $(20 \mathrm{~cm}$ height) and watered daily. To select the pot volume for the experiment, we determined seedling mean daily transpiration rate and selected a pot size that would ensure water availability above the standard permanent wilting point (soil moisture at $-1.5 \mathrm{MPa}$; $22 \% \mathrm{vol} / \mathrm{vol}$ ) for at least 1 week without watering (Trillo and Fernández 2005). The soil was sandy loam (clay $=6.6 \%$, silt $=41.9 \%$, sand $=51.5 \%$ ) similar to the soils in which natural forests grow.

\section{Mitigation of excess radiation in leaves}

In order to determine the application dose of Surround ${ }^{\circledR}$ WP (BASF Company, $K a$; commercial Kaolin) for subsequent treatment of the seedlings (see below), the covering power of $K a$ was determined by measuring the transmittance values, the amount of photosynthetic flux density (PPFD), and variation in the amounts of red and far red radiation ( $\mathrm{R}$ and FR, respectively) of glass plates of known area $\left(0.4 \mathrm{~m}^{2}\right)$ sprayed at four different doses (pure water, $60 \mathrm{~g} \mathrm{l}^{-1}$ in one and two applications and $80 \mathrm{~g} \mathrm{l}^{-1}$ in a single application). The glass plates were weighed before and after spraying to determine the amount of $\mathrm{Ka}$ per surface area $\left(\mathrm{m}^{-2}\right)$ of each dose. Four plates were used per dose and spray treatment.

To record the effect of the application of $K a$ on the photosynthetic performance of the three species (A. chilensis, $P$. menziesii and $P$. ponderosa), 20 seedlings per species were used. Ten seedlings per species were sprayed with an aqueous solution of $60 \mathrm{~g} \mathrm{l}^{-1}$ Surround ${ }^{\circledR}$ WP, while the remaining ten seedlings were sprayed only with de-ionized water. Plants were sprayed only once at the beginning of the growing season (November 2012).

Net photosynthesis rate at saturating PPFD (Asat; $\mu \mathrm{mol} \mathrm{CO}_{2} \mathrm{~m}^{-2} \mathrm{~s}^{-1}$ at $1000 \mu \mathrm{mol}$ photons $\left.\mathrm{m}^{-2} \mathrm{~s}^{-1}\right)$, stomatal conductance to water vapor $\left(g s, \mathrm{~mol} \mathrm{H}_{2} \mathrm{O} \mathrm{m}^{-2} \mathrm{~s}^{-1}\right)$, changes in the intrinsic water use efficiency (WUEi) and transpiration rates $\left(\mathrm{E}, \mathrm{mmol} \mathrm{H}_{2} \mathrm{O} \mathrm{m}^{-2} \mathrm{~s}^{-1}\right.$ ) were evaluated on six dates during the 2012-2013 growing season (12/12/2012;01/05/ 
2013; 01/18/2013; 02/01/2013; 02/15/2013 and 03/01/2013) for all the seedlings per species and treatment. Additionally, on a single date in December 2012, net photosynthesis rate $\left(A_{\mathrm{n}} ; \mu \mathrm{mol} \mathrm{CO} \mathrm{CO}_{2} \mathrm{~m}^{-2} \mathrm{~s}^{-1}\right)$ vs. PPFD curves were plotted by using seven radiation intensities $\left(0,50,100,250,500,1000\right.$ and $1200 \mu \mathrm{mol}$ photons $\left.\mathrm{m}^{-2} \mathrm{~s}^{-1}\right)$ for at least four seedlings per species and treatment.

All measurements were taken on sunny days between 10:00 a.m. and 1:00 p.m. using a LI-6400 portable photosynthesis measuring system (LI-COR, Lincoln, NE, USA) with a 6400-02B LED source. Each measurement was taken using a minimum waiting time of $180 \mathrm{~s}$ at each light intensity level and a $3 \%$ coefficient of variation. The chamber temperature was set at the same temperature of the air and leaf temperature was measured with a thermocouple inserted inside the chamber. $\mathrm{CO}_{2}$ partial pressure was set at $400 \mu \mathrm{mol} \mathrm{mol}^{-1}$. Airflow was set at $500 \mu \mathrm{mol} \mathrm{s}^{-1}$ to maintain the $\Delta \mathrm{CO}_{2}$ greater than the sensitivity threshold of the LI-6400 $\left(5 \mu \mathrm{mol} \mathrm{mol}^{-1}\right)$. Throughout the assay, greenhouse temperature was $20.8 \pm 6.3{ }^{\circ} \mathrm{C}$, relative humidity was $51.2 \pm 16.5 \%$ and radiation (PPFD) was always above the light compensation point for all the species.

\section{Mitigation of water shortage in soil}

For each of species, the effect of a single dose application of a synthetic polymer ( $G f$, Gelforest $^{\circledR}$, Tubron S.A.) with high water absorption capacity was evaluated using the dose indicated by the manufacturer, $1 \%$ of the total soil volume of the soil used in containers (pots).Twenty seedlings per species were transplanted to 3-1 plastic pots. Prior to this, the substrate of ten pots per species was mixed with $G f$ and ten pots were filled without $G f$ (control). At the beginning of the assay, all pots were irrigated to field capacity and wrapped in polythene bags to prevent direct evaporation from the soil surface of the pot. After this, irrigation was suspended. All the pots were weighed every 2 days in order to record water loss. On several dates, soil moisture was measured using a TDR device (Hidrosence, Campbell Scientific, US). Both measurements were used to plot dehydration curves for each species and treatment. Leaf stomatal conductance $\left(g s, \mathrm{~mol} \mathrm{H}_{2} \mathrm{O} \mathrm{m}^{-2} \mathrm{~s}^{-1}\right.$; a proxy of photosynthesis rate) was measured on five dates during the 2012-2013 growth season $(12 / 04 / 12 ; 01 / 04 / 13 ; 01 / 17 / 13 ; 01 / 30 / 13 ; 02 / 14 / 13)$ at midmorning (9:00 a.m. to 11:00 a.m.) and noon (2:00 p.m. to 4:00 p.m.) with a steady state PMR-5 porometer designed to be used with EGM-4 CO2 analyzer (PP Systems, Amesbury, USA).

\section{Damage mitigation of frost events}

In order to evaluate the effectiveness of NU-FILM-17 ${ }^{\circledR}$ (Miller Chemical and Fertilizer Corporation, Pennsylvania) in the most susceptible species (A. chilensis and P. menziesii) we used growth chambers (SAD-9000, Consultar Group, Rosario, Argentina) to simulate the most frequent frost event observed in the region.

Based on known physiological susceptibilities, we did not use $P$. ponderosa in this assay (see above).

Duration of tested frost event was based on average temperature records from 23 weather stations from the Watershed Inter-jurisdictional Authority and Secretariat of Water Resources, considering values beneath $0^{\circ} \mathrm{C}$ from October to March (growing season) for the period 1997-2013. From this subset, we calculated mean, average and minimum temperature for each station, and mean duration of the frost event. Based on this analysis we decided to subject the seedlings to $\mathrm{a}-3{ }^{\circ} \mathrm{C}$ frost for $3 \mathrm{~h}$. 
A group of 20 seedlings of each species was sprayed (once only in March 2013) using a knapsack sprayer with a $1.5 \%$ NU-FILM-17 ${ }^{\circledR}$-Water solution, while 20 seedlings were kept unsprayed. Ten sprayed and ten unsprayed seedlings of each species were placed in one of the chambers and subjected to a $3-\mathrm{h},-3{ }^{\circ} \mathrm{C}$ frost event by reducing the temperature gradually from $20^{\circ} \mathrm{C}$ (at a rate of reduction of $5{ }^{\circ} \mathrm{C}$ per hour). The remaining seedlings (ten sprayed and ten unsprayed per species) were kept under suboptimal conditions at $20{ }^{\circ} \mathrm{C}$. All seedlings were maintained with a suitable supply of water and under light conditions (PPFD) above their compensation point and below light saturation point (approximately $700 \mu \mathrm{mol}$ photons $\mathrm{m}^{-2} \mathrm{~s}^{-1}$ ).

Net photosynthetic rate at saturating PPFD (Asat, $\mu$ mol $\mathrm{CO}_{2} \mathrm{~m}^{-2} \mathrm{~s}^{-1}$ ), transpiration rates (E) and intrinsic water use efficiency (WUEi) were measured using an LI-COR 6400 prior to (December 2012) and after application of NU-FILM-17 ${ }^{\circledR}$, before subjecting the seedlings to the frost event in growth chambers, immediately after the frost event $(3 \mathrm{~h}$ at $3{ }^{\circ} \mathrm{C}$ ), and after 24 and $48 \mathrm{~h}$ (different days in February 2013). Because it was a short-term experiment, neither allometric nor morphological aspects were quantified.

\section{Statistical analysis}

Differences between transmitted PPFD, R, FR and R/FR of the different $\mathrm{Ka}$ application doses were compared using one-way ANOVA. The interactive effect of species, application of $K a$ and time of evaluation (Time) on Asat, gs, WUEi and E variables, due to the factorial completely randomized design of the $K a$ assay (with repeated non equally spaced measurements over time on the same experimental unit), were analyzed using linear mixed models(LMM). A Euclidean exponential spatial covariance correlation structure was used.

In cases in which significant differences were detected, Bonferroni's post hoc test was applied. Analyses were performed using Extended and LMM in InfoStat Version 2014 (Di Rienzo et al. 2014; Grupo InfoStat, FCA, UNC, Argentina). Interactions among all the factors were tested. When the triple interaction or any of the two-way interactions were significant, the hypotheses of interest were tested within species. In all cases, $\alpha=0.05$ was considered. LMM were used to analyze differences in $g s$ records between species and treatments over time in the $G f$ application assay, and differences between Asat, E and WUEi per treatment over time for the NU-FILM $17^{\circledR}$ application assay, in which LMM was used to analyze the two species separately. Additionally, in this assay and in order to test for the homogeneity of the experimental units, initial records (12/09/13) of Asat, WUEi and $\mathrm{E}$ were compared between treatments for each species using a two-way ANOVA. The record of the first assay measurement was used as covariate in the LMM model for all the mentioned response variables in order to correct for possible differences in initial individual values of the study variables.

Particularly for the $A_{\mathrm{n}}$ versus PPFD curves of the $K a$ assay, the datasets per species and treatment were fitted to a non-rectangular hyperbola model (Marshall and Biscoe 1980; Cannell and Thornley 1998). This leaf photosynthesis function has three parameters:

$$
A_{n}=\frac{1}{2 \theta}\left\{\alpha \times I i+A_{\max }-\left[\left(\alpha \times I i+A_{\max }\right)^{2}-4 \theta \times \alpha \times I i \times A_{\max }\right]^{1 / 2}\right\}
$$

where $A_{\mathrm{n}}$ represents net photosynthetic rate $\left(\mu \mathrm{mol} \mathrm{CO}_{2} \mathrm{~m}^{-2} \mathrm{~s}^{-1}\right), A_{\max }$ is the maximum saturated photosynthetic rate (the asymptote), $I i$ is the incident radiation (mol m${ }^{-2} \mathrm{~s}^{-1}$ PPFD), $\alpha$ is apparent quantum yield or radiation use efficiency $\left(\mu \mathrm{mol} \mathrm{CO}_{2} \mathrm{~mol}^{-1} \mathrm{PPFD}\right)$ 
and $\theta$ is the curvature (convexity, dimensionless) of the radiation-photosynthesis relationship.

The dataset was fit to a non-rectangular hyperbola model (Eq. 1) by using non-linear regression in Prism4 (GraphPad, San Diego, CA, USA). The accuracy of the fitted parameters was examined via the ratios between the standard errors of estimate (SEE) and the best fitted values (Zar 1999). We used global fitting (Motulsky and Christopoulus 2004) to compare the fitted parameters of the non-rectangular hyperbola equation between the different treatments within species. In each case, we report the evidence ratio (ER) in favor of the better model, comparing global versus separate fitting to the data (Motulsky and Christopoulus 2004).When comparing two models, the probability of one model being correct can be divided by the probability of the other being correct to obtain the evidence ratio. The ratio indicates the relative likelihood of each model being correct. Higher ER values indicate the selection of one of the particular models versus the global model.

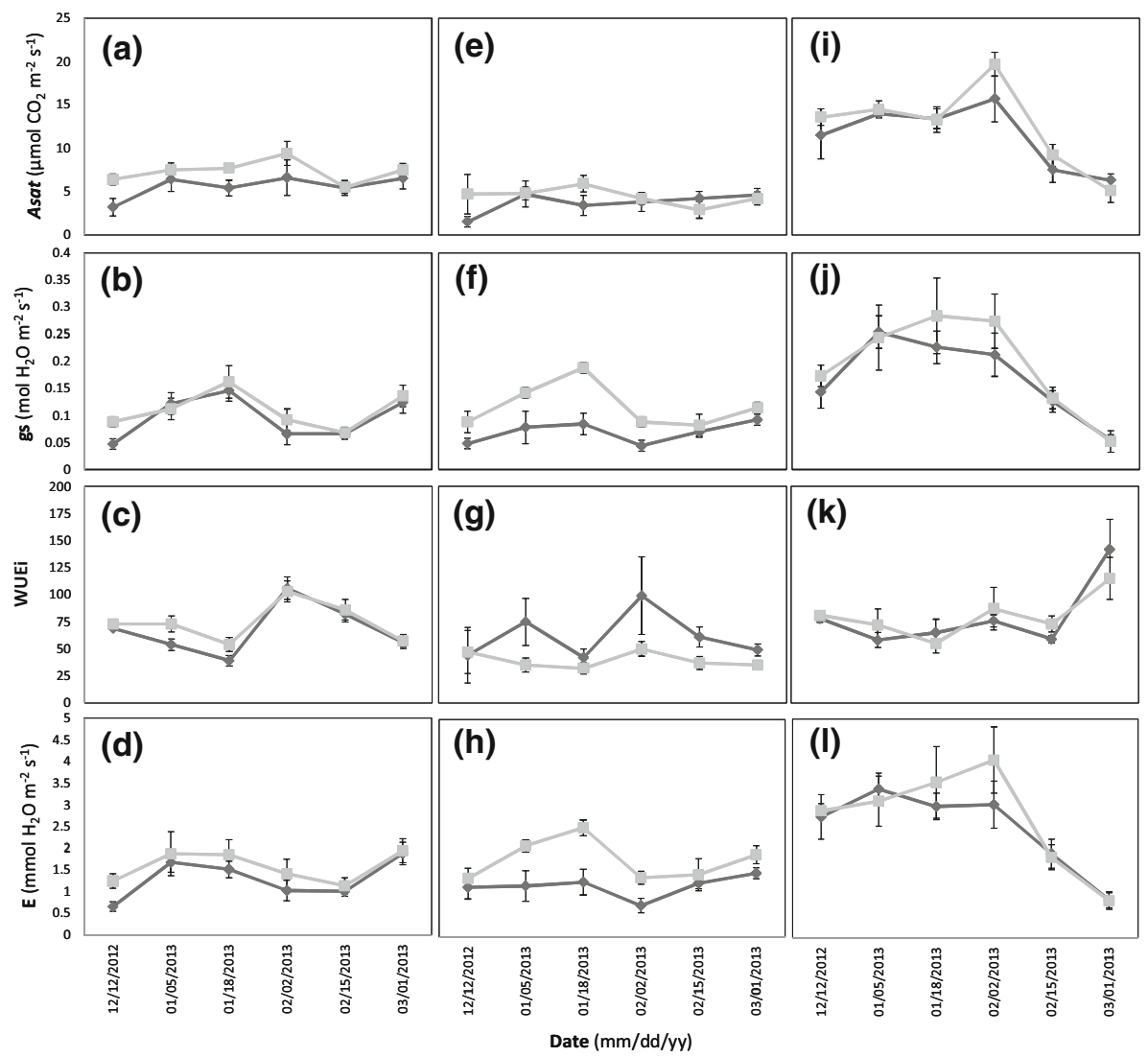

Fig. 1 Mean values $( \pm \mathrm{SD})$ of net photosynthetic activity at saturating PPFD (Asat; a, e, i panels), stomatal conductance ( $g s ; \mathbf{b}, \mathbf{f}, \mathbf{j}$ panels), intrinsic water use efficiency (WUEi; $\mathbf{c}, \mathbf{g}, \mathbf{k}$ panels) and transpiration rates (E; d, h, l panels) for A. chilensis (a-d panels), P. menziesii (e-h panels) and P. ponderosa (i-l panels) at the different times of register. Light gray square-solid lines represent the values of untreated seedlings; Dark gray diamond-solid lines represent the values of seedlings treated with Kaolinite. Statistically significant differences are commented in Table 1 
Dehydration curves of the $G f$ assay, for each species and treatment, were then fitted to one phase decay exponential models:

$$
Y=(Y 0-\text { Plateau }) \times \exp (-K \times X)+\text { Plateau }
$$

where $Y O$ is the value of $Y$ (humidity) when $X$ (time) is zero (date experiment started); Plateau is the $Y$ value at infinite time and $K$ is the rate constant, expressed in units of reciprocal time axis $X$ : If $X$ is in minutes, then $K$ is expressed in inverse minutes).

The data were adjusted to the exponential model (Eq. 2) by non-linear regression in Prism4 software (GraphPad, San Diego, CA, USA). In order to attain a biological interpretation of parameters, a constraint was set in the model to obtain values greater than 0 for the Plateau. The differences between the fitted parameters for each species and treatment were examined through the relationship between the standard error of estimate (SEE) and goodness of fit (Zar 1999). Global fit procedure (Motulsky and Christopoulus 2004) was used to compare the fitting parameters of the exponential equations. In each case, we report the evidence ratio (ER) in favor of the better model (i.e. global vs. separate fitting to the data; Motulsky and Christopoulos 2004). In cases where data did not fit the exponential model, a linear model was used. Data were adjusted to the linear models by linear regression using Prism4 software (GraphPad, San Diego, CA, USA).

\section{Results}

\section{Mitigation of excess radiation in leaves}

Results showed that the $K a$ applied in a single $60 \mathrm{~g} \mathrm{l}^{-1}$ dose had a covering power of $0.3 \mathrm{~g}$ $K a \mathrm{~m}^{-2}$, reducing the incident PPFD by $45 \pm 2 \%\left(350 \pm 11 \mu \mathrm{mol}\right.$ photons $\left.\mathrm{m}^{-2} \mathrm{~s}^{-1}\right)$. A greater reduction of incident PPFD was observed for the 60 (two applications) and $80 \mathrm{~g}^{-1}$ doses, which resulted in PPFD reductions of 68 and $56 \%$, respectively $(228 \pm 5$ and $313 \pm 30 \mu \mathrm{mol}$ photons $\mathrm{m}^{-2} \mathrm{~s}^{-1}$; data not shown). Their covering power was 1.2 and $0.5 \mathrm{~g} \mathrm{Ka} \mathrm{m}^{-2}$. Additionally, R, FR and the R/FR values were higher for the control and lower for $60 \mathrm{~g} \mathrm{l}^{-1}$ (two applications) $K a$ dose $\left(p<0.05\right.$ ). Therefore, a $K a$ dose of $60 \mathrm{~g} \mathrm{l}^{-1}$ was used for subsequent treatment of the seedlings.

Table 1 Significances of the mixed lineal model analysis of the Ka essay

\begin{tabular}{|c|c|c|c|c|}
\hline \multirow[t]{2}{*}{ Significance } & \multicolumn{4}{|l|}{ Variable } \\
\hline & Asat & $g s$ & WUEi & $\mathrm{E}$ \\
\hline$p_{\text {species }}$ & $<0.0001$ & $<0.0001$ & $<0.0001$ & $<0.0001$ \\
\hline$p_{\text {treat }}$ & 0.0433 & 0.0094 & n.s. & 0.014 \\
\hline$p_{\text {time }}$ & $<0.0001$ & $<0.0001$ & $<0.0001$ & $<0.0001$ \\
\hline$p_{\text {species }}{ }^{*}$ treat & n.s. & n.s. & 0.0156 & n.s. \\
\hline$p_{\text {species }}{ }^{*}$ time & $<0.0001$ & $<0.0001$ & $<0.0001$ & $<0.0001$ \\
\hline$p_{\text {treat }} *$ time & n.s. & n.s. & n.s. & n.s. \\
\hline$p_{\text {species }}{ }^{*}$ treat $*$ time & n.s. & n.s. & n.s. & n.s. \\
\hline
\end{tabular}

Asat net photosynthetic rates at saturating PPFD, gs stomatal conductance, WUEi intrinsic water use efficiency, $E$ transpiration rates, $n$. s. non statistical differences

Statistical differences are commented on the text 
Significant interaction between species and date was detected for Asat (Fig. 1; Table 1). On most dates Asat was higher in $P$. ponderosa than in the other species. This difference was large at the beginning of the assay and decreased towards the end of the growing season (orderly interaction; sensu Ott and Longnecker 2010). The treatment was also found to affect Asat. Independently of the species or date, mean Asat values were higher for seedlings treated with $K a$ than for control seedlings (Fig. 1; Table 1). On average, $K a$ increases Asat a $31 \%$ in A. chilensis; $20 \%$ P. menziesii and $10 \%$ in P. ponderosa seedlings compared to control seedlings.gs and E showed the same pattern as Asat. Seedlings treated with $K a$ showed an average increase of 15, 69 and $14 \%$ for $g s$ and 22, 52 and $9 \%$ for E in A. chilensis, P. menziesii and P. ponderosa, respectively (Fig. 1; Table 1).

Particularly for WUEi, significant interaction was found between species and treatment (also between species and time, as in the other variables) (Fig. 1; Table 1): A. chilensis and $P$. ponderosa seedlings treated with $K a$ showed a trend to similar WUEi values as control seedlings, while $P$. menziesii seedlings treated with $K a$ showed a smoother pattern than control seedlings, with a tendency to lower values.

The parameters derives from the $A_{\mathrm{n}}$-PPFD curves showed differences between the control and $K a$ only for $A$. chilensis (ER = tending to infinity); plants with $K a$ had a higher rate of maximum photosynthesis $\left(A_{\max }\right)$ (Table 2$)$.

\section{Mitigation of water shortage in soil}

In all species and through the study period soil water volume content was higher in $G f$ than in the control $\left(\mathrm{ER}_{A \text {. chilensis }}, \mathrm{ER}_{P . \text { menziesii }}\right.$ and $\mathrm{ER}_{P \text {. ponderosa }}=$ tending to infinity; Fig. 2; Table 3). Initial soil water availability was higher in $G f$ than control treatment (about $40 \%$ against 60-80\%, respectively; Fig. 2). Gf delays the time at which soil moisture attains a soil water potential of $-1.5 \mathrm{MPa}$ by 48,87 and 74 days in A. chilensis; P. menziesii and $P$. ponderosa respectively (Fig. 2). Differences between models were due to differences in $Y O$ and $K$ parameters in all the species (Table 3).

Interaction effects were found between species and treatment and between species and

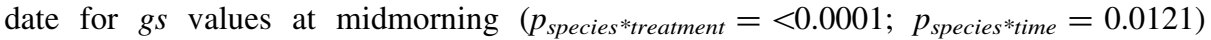
(Fig. 3). There was a marginal significant interaction effect between treatment and time in

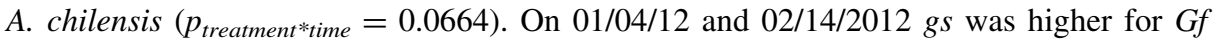
than for the control while the rest of the days differences in $g s$ were not significant. On the

Table 2 Average parameters and goodness of fit derived from the $A_{\mathrm{n}}$-PPFD curves (Cannell and Thornley 1998)

\begin{tabular}{lcccccc}
\hline Parameters/goodness of fit & $A c-C$ & $A c-K a$ & $P m-C$ & $P m-K a$ & $P p-C$ & $P p-K a$ \\
\hline$\alpha$ & $0.01 \mathrm{a}$ & $0.08 \mathrm{a}$ & $0.02 \mathrm{a}$ & $0.30 \mathrm{a}$ & $0.03 \mathrm{a}$ & $0.05 \mathrm{a}$ \\
$A_{\max }$ & $2.7 \mathrm{~b}$ & $6.2 \mathrm{a}$ & $2.5 \mathrm{a}$ & $4.1 \mathrm{a}$ & $12.5 \mathrm{a}$ & $14.5 \mathrm{a}$ \\
$\Theta$ & $-0.43 \mathrm{a}$ & $-0.03 \mathrm{a}$ & $1.00 \mathrm{a}$ & $-18.68 \mathrm{a}$ & $0.81 \mathrm{a}$ & $0.68 \mathrm{a}$ \\
$R^{2}$ & 0.8019 & 0.6927 & 0.3952 & 0.2191 & 0.7215 & 0.8868 \\
\hline
\end{tabular}

$\alpha$ apparent quantum yield $\left(\mathrm{mol} \mathrm{CO} \mathrm{Col}^{-1}\right), A_{\max }$ maximum rate of net photosynthesis at saturating PPFD $\left(\mu \mathrm{mol} \mathrm{CO} 2 \mathrm{~m}^{-2} \mathrm{~s}^{-1}\right.$ ), $\theta$ curvature factor (dimensionless), Ac mountain cypress (A. chilensis), Pm Douglas fir (P. menziesii), Pp Ponderosa pine (P. ponderosa), -C Control, -Ka Kaolinite (Surround ${ }^{\circledR}$ WP)

For each species and within rows, different lowercase letters show statistically significant differences between treatments 

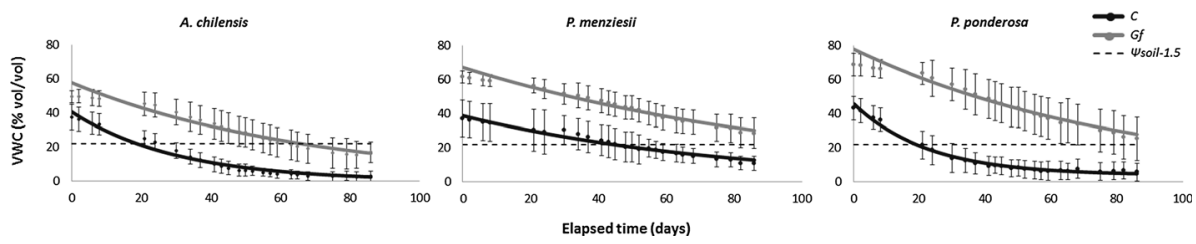

Fig. 2 Exponential/linear models fitted to the dehydration curves (volumetric water content in pots $=$ VWC vs. Elapsed time) by treatment and species. Statistical differences between treatments within species are mentioned in the text. $C=$ control; $G f=$ Gelforest seedlings; $\Psi_{\text {soil-1.5 }}$, soil moisture at which soil attain $-1.5 \mathrm{MPa}$ (standard permanent wilting point)

Table 3 Mean values of the estimated parameters of exponential and linear models and goodness of fit by species and treatment

\begin{tabular}{|c|c|c|c|c|c|c|}
\hline \multirow[t]{3}{*}{ Exponential models } & \multicolumn{6}{|c|}{$\mathrm{Y}=\left(\mathrm{Y}_{0}-\right.$ Plateau $) \times \exp (-\mathrm{K} \times \mathrm{X})+$ Plateau } \\
\hline & \multicolumn{2}{|c|}{ A. chilensis } & \multicolumn{2}{|c|}{ P. menziesii } & \multicolumn{2}{|c|}{ P. ponderosa } \\
\hline & $C$ & $G f$ & $C$ & $G f$ & $C$ & $G f$ \\
\hline Y0 & 40.65 & 57.75 & 38.93 & 67.26 & 45.84 & 77.97 \\
\hline Plateau & $1.2^{-16}$ & $4.21^{-11}$ & $1.63^{-16}$ & $1.13^{-10}$ & 3.93 & $4.44^{-11}$ \\
\hline $\mathrm{K}$ & 0.03286 & 0.01466 & 0.01283 & 0.009296 & 0.04424 & 0.01192 \\
\hline $\mathrm{R}^{2}$ & 0.8672 & 0.7042 & 0.4813 & 0.7224 & 0.8101 & 0.6489 \\
\hline
\end{tabular}

$C=$ control, $G f=$ Gelforest seedlings

contrary, $G f$ significantly reduced $g s$ in $P$. ponderosa $\left(p_{\text {treatment }}=0.0078\right)$ while no significant effect was observed in P. menziesii (Fig. 3).

Stomatal conductance at noon was lower and less variable than at midmorning. An

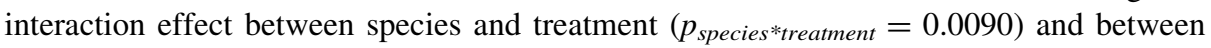

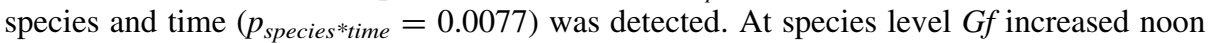
$g s$ in $P$. menziesii $\left(p_{\text {treatment }}=0.0049\right)$ and a marginally reduced it in $P$. ponderosa $\left(p_{\text {treatment }}=0.0577\right)$. $P$. menziesii seedlings treated with $G f$ tended to have higher $g s$ values than control seedlings, and an opposite trend was observed in $P$. ponderosa meanwhile no differences between treatments or times were found for A. chilensis (Fig. 3).

\section{Damage mitigation of frost events}

When the Asat, WUEi and E values recorded on the first date are analyzed for each species separately, the seedlings in all the sub-groups (treatments per species) show similar mean values for all the variables $(p>0.05)$. Mean values for Asat, WUEi and E were $2.07 \pm 0.86 ; 19.53 \pm 5.8 ; 0.36 \pm 0.28$ for P. menziesii and $3.11 \pm 0.79 ; 12.71 \pm 10.81$; $0.36 \pm 0.22$ for $A$. chilensis, respectively.

The Asat values for P. menziesii showed no interaction effect between treatment and

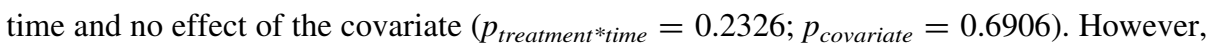
we did find an effect of treatment $\left(p_{\text {treatment }}=<0.0001\right)$ and time $\left(p_{\text {time }}=0.0063\right)$. $P$. menziesii control seedlings at $20{ }^{\circ} \mathrm{C}$ had the highest Asat values, followed by control seedlings at $-3{ }^{\circ} \mathrm{C}$ and seedlings treated with NU-FILM at both temperatures. In general 
Fig. 3 Mean values of stomatal conductance $(g s)( \pm \mathrm{SD})$ at midmorning (circles-solid lines) and noon (triangles-dash lines) for different species and treatments. White circles and triangles (with thin lines) show the gs values recorded for control seedlings. Black circles and triangles (with gross lines) show the gs values recorded for seedlings treated with Gelforest $(G f)$. Statistically significant differences are commented in the text

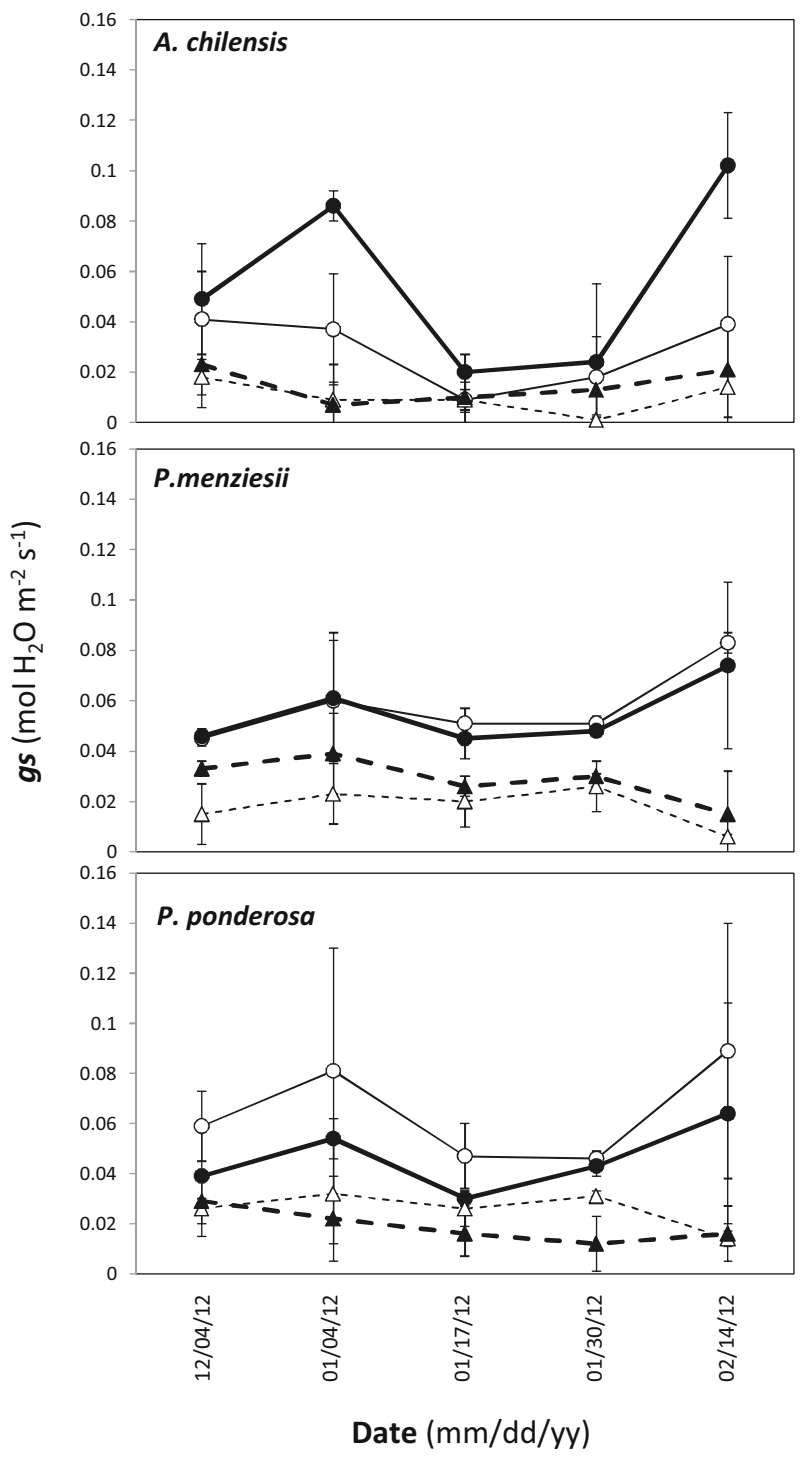

terms, the controls had higher mean Asat values than seedlings treated with NU-FILM$17^{\circledR}$.

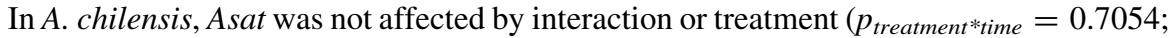
$p_{\text {treatment }}=0.1681$; Fig. 4b), but was affected by time $\left(p_{\text {time }}=<0.0001\right)$.

For transpiration rates $(\mathrm{E})$, an interaction effect between treatment and time was found for P. menziesii ( $p_{\text {treatment }} *$ time $=0.0152$; Fig. $4 \mathrm{c}$ ). In general terms, the seedlings under control treatment at $20{ }^{\circ} \mathrm{C}(C 20)$ had higher transpiration rates than the seedlings under the remaining treatments. On the first recording date, the values for the $C 20$ seedlings were similar to those for the control seedlings at $-3{ }^{\circ} \mathrm{C}(C-3)$. For the last recording date (Fig. 4c), the values for $C 20$ seedlings were similar to those for $C$-3 and seedlings treated 

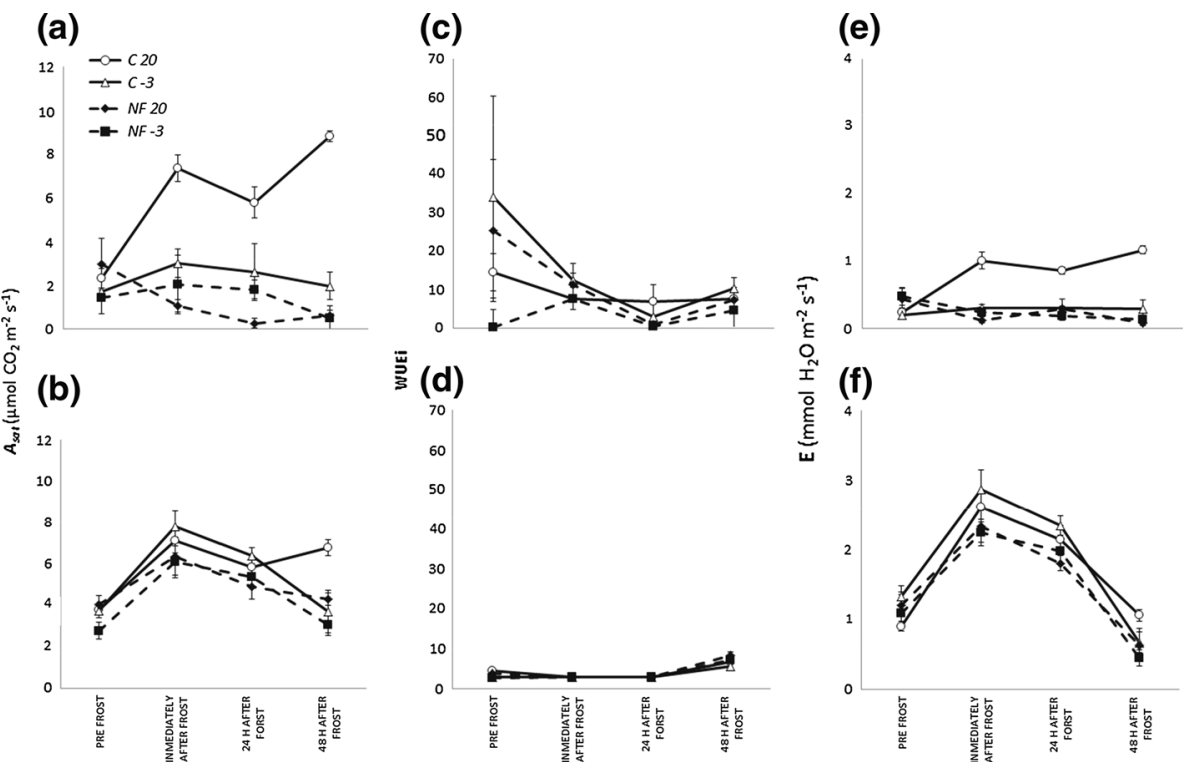

Fig. 4 Mean values $( \pm S D)$ of net photosynthetic rates at saturating PPFD (Asat; a, b), transpiration rates (E; c, d) and intrinsic water use efficiency (WUEi; e, f) on P. menziesii (upper panels) and A. chilensis (lower panels) at different times of measurement. References: $C$ 20, plants without application of NUFILM-17 at $20{ }^{\circ} \mathrm{C} ; C-3$, plants without application of NU-FILM-17 submitted to treatment of $-3{ }^{\circ} \mathrm{C} ; N F$ 20 , plants with NU-FILM-17 application at $20^{\circ} \mathrm{C} ; N F-3$, plants with NU-FILM application submitted to treatment of $-3{ }^{\circ} \mathrm{C}$. Statistical differences are commented in the text

with NU-FILM- $17^{\circledR}$ at $-3{ }^{\circ} \mathrm{C}(N F-3)$ and different from those for $N F 20$ seedlings. In the

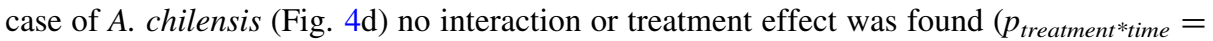
$\left.0.1330 ; p_{\text {treatment }}=0.3970\right)$, although there was a significant effect of time $\left(p_{\text {time }}<\right.$ 0.0001).

For WUEi (Fig. 4e, f), no treatment effect or interaction between factors was found for

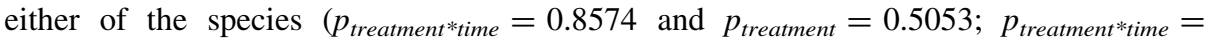
0.6331 and $p_{\text {treatment }}=0.5153$ for $P$. menziesii and A. chilensis, respectively). An effect of time was found for P. menziesii ( $p_{\text {time }}=0.0068$ ), in which the highest WUEi value was found immediately after the frost event.

\section{Discussion}

In this study, Kaolin does not reduce Asat, $g s$ or WUEi, in spite of reducing the amount of radiation. The selected dose reduces incident PPFD by approximately $40-50 \%$, in agreement with previous studies (e.g. Jifon and Syvertsen 2003; Steiman et al. 2007) and increase Asat in all species, with a marked effect on A. chilensis, which increased Asat in $100 \%$. Our results are contrary to results in Rosati (2007) for other species. Additionally, A. chilensis showed increases in the $A_{\max }$ values of $A_{\mathrm{n}}$ versus PPFD curves and no variation in WUEi levels. It should be emphasized that the $A_{\max }$ values of the remaining species also increased by up to two units (Table 2). It is important to highlight that the irrigation system used in this study (fogger) enabled the single application of Kaolin to last until the end of 
the trial, without being washed out. A higher application frequency might be needed for Kaolin to have a positive effect on seedling gas exchange variables in the field. Preliminary results from our field experiments show $A_{\text {max }}$ increases between 2 and $10 \mu \mathrm{mol} \mathrm{CO}_{2} \mathrm{~m}^{-2}$ $\mathrm{s}^{-1}$, and increases of $2-5 \mu \mathrm{mol} \mathrm{CO} \mathrm{CO}^{-2} \mathrm{~s}^{-1}$ in Asat values for plants treated with Kaolin compared to control seedlings for $A$. chilensis and $P$. menziesii respectively ( $p_{\text {treatment }}=$ 0.0033, Varela et al., unpublished data). In these assays, Kaolin was applied every 2 months throughout the growing season (November to April).

As mentioned in the introduction, the survival of young A. chilensis trees in this region is highly correlated to the presence of shrubs. This is known as the "nurse syndrome" and involves the amelioration of micro-environmental variables under a plant - the nurse which enhances survivorship and/or growth of other species growing in association with it (Niering et al. 1963). Our results show that $\mathrm{Ka}$ could have some beneficial effect on this aspect (mainly on the damage caused by excess radiation). The mechanisms of action of $K a$ applications are not clear. Although the increased albedo reduces leaf temperature and the consequent heat stress, it also reduces the available light for photosynthesis, possibly offsetting the benefits of lower temperature (Rosati et al. 2006). On the contrary, $P$. ponderosa had the highest carbon fixation rates and did not show any effect as a result of $K a$ application. Studies on other species have shown inconsistent results. This inconsistency may be linked to variation in application techniques, $K a$ coverage and subsequent effects on light transmission, leaf temperature and physiological function.

Volumetric soil water contents in pots with $G f$ were higher than in controls, but stomatal conductance varied according to the study species. gs values increased in A. chilensis, decreased in $P$. ponderosa, and remained similar in $P$. menziesii. Few studies have focused on how development and physiology are affected by hydrogel. One of the first experiments was conducted in Arizona, USA in 1972-1973. It found that hydrogel reduced germination rates and survival of emerged $P$. ponderosa seedlings (Rietveld 1976). The hydrogel dose we used may not be appropriate for all forest species. Although hydrogels are simple to apply, it is quite difficult to avoid an overdose which will cause plant mortality. Maybe, the tolerance to waterlogging could explain our results based on that $P$. ponderosa showed a lower tolerance that $P$. mensiezii to this source of stress (Niinemets and Valladares 2006). Some authors have suggested that research should be carried out to determine suitable doses for different soil types and tree species (Boczón et al. 2009). A review by Flexas et al. (2004) used $g s$, chlorophyll fluorescence and gas exchange parameters as indicators of the severity of water stress, suggesting that photosynthetic metabolism is progressively down-regulated as water stress intensifies. Three stages of photosynthesis inhibition were described: Stage 1) As $g s$ decreases from its maximum value (remarkably, irrespective of the actual value, which was largely variable depending on the species) to about $0.15 \mathrm{~mol}$ $\mathrm{H}_{2} \mathrm{O} \mathrm{m}^{-2} \mathrm{~s}^{-1}$, net photosynthesis $\left(A_{\mathrm{n}}\right)$ decreases slowly with very small variations of Asat and no variation of the photosynthetic electron transport rate (ETR). Intrinsic water-use efficiency progressively increases at this stage. Stage 2) When $g s$ drops to between 0.15 and $0.05 \mathrm{~mol} \mathrm{H}_{2} \mathrm{O} \mathrm{m}^{-2} \mathrm{~s}^{-1}, A_{\mathrm{n}}$ and Asat decrease further, and so does ETR, suggesting increased metabolic limitations. However, a continuous decline in sub-stomatal $\mathrm{CO}_{2}$ concentration $(\mathrm{Ci})$ suggests that stomatal closure is still the dominant limitation to photosynthesis. It is also suggested that mesophyll conductance to $\mathrm{CO}_{2}$ begins to decline at this stage. Intrinsic water-use efficiency still increases at this stage, reaching maximum values at $g s$ values of about $0.05 \mathrm{~mol} \mathrm{H}_{2} \mathrm{O} \mathrm{m}^{-2} \mathrm{~s}^{-1}$. Stage 3) When $g s$ declines to less than $0.05 \mathrm{~mol} \mathrm{H}_{2} \mathrm{O} \mathrm{m}^{-2} \mathrm{~s}^{-1}, \mathrm{Ci}$ usually increases sharply, reflecting either erroneous estimations of $\mathrm{Ci}$ or impaired photosynthetic metabolism. Intrinsic water use efficiency usually decreases at this stage, and both Asat and ETR become very low. Based on these stages, 
seedlings of all the species we considered had limitations due to water stress during the assay (being between stages 2 and 3). However, particularly in the case of A. chilensis, Gf application caused the seedlings to maintain their water status for longer in Stage 2. This trend was not observed in P. menziesii and the pattern is opposite in P. ponderosa. Particularly for the latter species, the higher VWC generated by $G f$ could have a negative effect on $g s$ values. In the present study $G f$ delays the time at which soil moisture attains a soil water potential of $-1.5 \mathrm{MPa}$ by 48,87 and 74 days in A. chilensis; $P$. menziesii and $P$. ponderosa respectively. In Northern Patagonia, the average number of days without precipitation during the growing season ranges from 10 to 20 , and the longest period without rain on record is 110-180 days (Bianchi unpublished data).

It is important to highlight that the potential benefit of using water retention polymers at planting has been demonstrated in laboratory tests and container trials (e.g. Forestry Commission and Liverpool University). However, it was concluded that polymers were unlikely to benefit newly planted trees in terms of survival during long periods of drought (Hodge 1991). Trials in Kenya which used by mycorrhizal inoculum and water retaining polymers found increased tree survival with the use of inoculum, but detrimental effects as a result of the use of polymers (Wilson et al. 1991). However, their use in Sudan with transplanted Eucalyptus spp. seedlings led to an increase in survival (Callaghan 1989). Overall, there is little to support the use of water retaining polymers for field use. Preliminary results from field assays did not show significant statistical differences in this variable for seedlings treated with hydrogel compared to control seedlings $(p>0.05$; Varela et al. unpublished data).

Field assays evaluating the synergy among the various stress factors and the water status of seedlings and the evaluation of the response of different species are needed to test the effectiveness of the abovementioned mitigation techniques.

Applying NU-FILM-17 ${ }^{\circledR}$ as a frost mitigation technique does not seem to be suitable. There was no change in any of the ecophysiological measurements for A. chilensis after treatment. In contrast, photosynthesis at non-stressing temperature level was inhibited in $P$. menziesii. A similar pattern was found using transpiration as a response, which means that NU-FILM-1 $7^{\circledR}$ reduces the water uptake of P. menziesii at the higher temperature. The few previous studies which have been published evaluate the use of another antitranspirant (e.g. Foli-gard; Roy 1966) on P. menziesii, report that the height of seedlings treated with Foligard anti-desiccant increased more than that of untreated control seedlings. We did not evaluate NU-FILM-17 ${ }^{\circledR}$ in $P$. ponderosa, but previous studies of film-forming anti-desiccants show a negative effect on the growth of new roots and a delay in budbreak activity. Moreover, several experiments (Vera-Castillo 1995) have shown that anti-desiccants had no effect on photochemical efficiency, with little effect on $P$. ponderosa seedlings. The potentiality of this technique should be tested in field assays.

\section{Conclusion}

Our results suggest that is not possible to develop a single general package of techniques for optimizing the planting and establishment process which will meet the requirements of all three study species, because each species has different susceptibility to environmental stress. $P$. ponderosa, the most tolerant species, showed a negative response in gas exchange traits to the application of $G f$ technique. In contrast, $K a$ and $G f$ had a positive effect on $A$. chilensis. The frost mitigation technique was not suitable for any of the species, but 
appears to be positive as an anti-desiccant for $P$. menziesii. Field experiments should be performed to recommend several of the treatments tested in our study.

Acknowledgments We wish to thank Rocio Marticorena from Watershed Interjurisdictional Authority (AIC) for meteorological data and the Forest Ecology Group of INTA EEA Bariloche staff for their help with laboratory assays. Improvement of the English manuscript and valuable suggestions on an earlier draft of the manuscript are owed to Priscilla Edwards. This study was supported by Applied Research Project PIA10024 "Development of planting technology under environmental stress conditions for major conifers used in NW Patagonia". Project for Sustainable Management of Natural Resources BIRF 7520 AR. Component 2: Sustainable Forestry Plantations.

Conflict of interest The authors declare that they have no conflict of interest.

\section{References}

Aitken SN, Yeaman S, Holliday JA, Wang T, Curtis-McLane S (2008) Adaptation, migration or extirpation: climate change outcomes for tree populations. Evol Appl 1(1):95-111. doi:10.1111/j.1752-4571.2007. 00013.x

Aparicio AG (2014) Variación genética de la adaptación inicial del ciprés de la Cordillera. Tesis de la carrera de Doctorado en Biología. CRUB, UNCo. San Carlos de Bariloche, pp 160

Beniwal RS, Mahinder SH, Polle A (2011) Amelioration of planting stress by soil amendment with a hydrogel-mycorrhiza mixture for early establishment of beech (Fagus sylvatica L.) seedlings. Ann For Sci 68:803-810. doi:10.1007/s13595-011-0077-z

Boczón A, Wróbel M, Wieslaw P (2009) Effects of hydrogel application on growth of seedlings on unproductive forest areas. Ekologija 55(1):9-19. doi:10.2478/v10055-009-0002-z

Burgos JJ (1971) Clima de la Provincia de Buenos Aires en relación con la vegetación natural y el suelo. Instituto Nacional de Tecnología Agropecuaria

Callaghan TY (1989) The effect of water absorbing polymers on the stomatal conductance, growth and survival of transplanted Eucalyptus microtheca seedlings in the Sudan. J Appl Ecol 26:663-672

Cannell MGR, Thornley JHM (1998) Temperature and $\mathrm{CO}_{2}$ responses of leaf and canopy photosynthesis: a clarification using non-rectangular hyperbola model of photosynthesis. Ann Bot 82:883-892

Cantore V, Pace B, Albrizio R (2009) Kaolin-based particle film technology affects tomato physiology, yield and quality. Environ Exp Bot 66:279-288

Chirino E, Vilagrosa A, Vallejo VR (2011) Using hydrogel and clay to improve the water status of seedlings for dryland restoration. Plant Soil 344:99-110

DeLucia EH, Schlesinger WH (1991) Resource-use efficiency and drought tolerance in adjacent Great Basin and Sierran plants. Ecology 72:51-58

Di Rienzo JA, Casanoves F, Balzarini MG, Gonzalez L, Tablada M, Robledo CW (2014) InfoStat versión 2014. Grupo InfoStat, FCA, Universidad Nacional de Córdoba, Argentina. http://www.infostat.com.ar

Fernández ME, Gyenge JE, Varela S, de Urquiza M (2014) Effects of the time of drought occurrence within the growing season on growth and survival of Pinus ponderosa seedlings. Trees Struct Funct 28:745-756. doi:10.1007/s00468-014-0986-1

Flexas J, Bota J, Cifre J, Escalona JM, Galmes J, Gulias J, Lefi E, Martínez-Cañellas SF, Moreno MT, Ribas-Carbó M, Riera D, Sampol B, Medrano H (2004) Understanding down-regulation of photosynthesis under water stress: future prospects and searching for physiological tools for irrigation management. Ann Appl Biol 144:273-283

Fuenzalida H, Falvey M, Rojas M, Aceituno P, Garreaud R (2006) Estudio de la variabilidad climática en Chile para el siglo XXI. Informe para la Comisión Nacional de Medio Ambiente (CONAMA), p 71

Gyenge JE, Fernández ME, Schlichter TM (2007) Influence of radiation and drought on gas exchange of Austrocedrus chilensis seedlings. Bosque 28(3):220-225

Hodge SJ (1991) Use of water-retentive materials in planting pits for trees. In: Hodge SJ (ed) Research for practical arboriculture. Forestry Commission. HMSO, London, pp 29-38

IPCC (2008) Climatic change and water. Intergovernmental panel on climate change (IPCC) Technical Paper VI. Bates B, Kundzewicz Z, Wu S, Palutikof J (eds) WMO \& UNEP

Jifon J, Syvertsen J (2003) Kaolin particle film applications can increase photosynthesis and water use efficiency of 'Ruby red' grapefruit leaves. J Am Soc Hortic Sci 128:107-112 
Jobbagy EG, Paruelo JM, León RJC (1995) Estimación del régimen de precipitación a partir de la distancia a la cordillera en el noroeste de la Patagonia. Ecol Austral 5:47-54

Kavanagh KL, Bond BJ, Aitken SN, Gartner BL, Knowe S (1999) Shoot and root vulnerability to xylem cavitation in four populations of Douglas-fir seedlings. Tree Physiol 19:31-37

Knight AL, Unruh TR, Christianson BA, Puterka GJ, Glenn M (2000) Effects of a kaolin-based particle film on Oliquebanded Leafroller (Lepidoptera: Torticidae). J Econ Entomol 93(3):744-749

Letourneau F (2006) El Ciprés de la Cordillera y las especies arbustivas durante la etapa de crecimiento inicial: estudio de las interacciones positivas y negativas sobre su crecimiento. Tesis presentada para optar al grado de Doctor en Biología. San Carlos de Bariloche, pp 182

Luo ZB, Janz D, Jiang XN, Göbel C, Wildhagen H, Tan YP, Rennenberg H, Feussner I, Polle A (2009) Upgrading root physiology for stress tolerance by ectomycorrhizas: insights from metabolite and transcriptional profiling into reprogramming for stress anticipation. Plant Physiol 151:1902-1917

Marshall B, Biscoe P (1980) A model for C3 leaves describing the dependence of net photosynthesis on irradiance. J Exp Bot 31:29-39

Melgarejo P, Martínez JJ, Hernández F, Martínez-Font R, Barrows P, Erez A (2004) Kaolin treatment to reduce pomegranate sunburn. Sci Hortic 100:349-353

Moftah AE, Al-Humaid ARI (2005) Effects of antitranspirants on water relations and photosynthetic rate of cultivated tropical plant (Polianthes tuberosa L.). Pol J Ecol 53:165-175

Motulsky HJ, Christopoulus A (2004) Fitting models to biological data using linear and non-linear regression. GraphPad Software Inc., San Diego

Niering WA, Whittaker RH, Lowe CH (1963) Thesaguaro: a population in relation to environment. Science 142:15-23

Niinemets Ü (2010) Responses of forest trees to single and multiple environmental stresses from seedlings to mature plants: past stress history, stress interactions, tolerance and acclimation. For Ecol Manag 260:1623-1639

Niinemets Ü, Valladares F (2006) Tolerance to shade, drought, and waterlogging of temperate northern hemisphere trees and shrubs. Ecol Monogr 76:521-547

Oliet JA, Jacobs DF (2012) Restoring forests: advances in techniques and theory. New For 43:535-541

Oliver WW, Ryker RA (1990) Pinus ponderosa Dougl. exLaws. In: Burns RM, Honkala BH (eds) Silvics of North America, Vol. 1, Conifers. USDA forest service agricultural handbook 654, Washington, pp 413-424

Ott RL, Longnecker M (2010) An introduction to statistical methods and data analysis, 6th edn. Brooks/Cole CENGAGE Learning, Belmont, pp 1296

Paruelo JM, Beltrán A, Jobbágy E, Sala OE, Golluscio RA (1998) The climate of Patagonia: general patterns and controls on biotic processes. Ecol Austral 8:85-101

Pratolongo P, Quintana R, Malvárez I, Cagnoni M (2003) Comparative analysis of variables associated with germination and seedling establishment for Prosopisnigra (Griseb.) Hieron and Acacia caven (Mol.) Mol. For Ecol Manag 179:15-25

Rietveld WJ (1976) Hydrophilic polymer reduces germination of Ponderosa Pine in seed spots. Tree Plant Notes 27:18-19

Rosati A (2007) Physiological effects of kaolin particle film technology: a review. Funct Plant Sci Biotech $1: 100-105$

Rosati A, Metcalf SG, Buchner RP, Fulton AE, Lampinen BD (2006) Physiological effects of kaolin applications in well-irrigated and water-stressed walnut and almond trees. Ann Bot 98:267-275

Roy DF (1966) Effects of a transpiration retardant and root coating on survival of Douglas-fir planting stock. Tree Plant Notes 79:10-12

SAGPyA (1999) Argentina, oportunidades de inversión en bosques cultivados. Secretaría de Agricultura, Ganadería, Pesca y Alimentación, Buenos Aires, pp 208

Savi T, Marin M, Boldrin D, Incerti G, Andri S, Nardini A (2014) Green roofs for a drier world: effects of hydrogel amendment on substrate and plant water status. Sci Total Environ 490:467-476. doi:10.1016/ j.scitotenv.2014.05.020

Shi Y, Li J, Shao J, Deng S, Wang RG, Li N, Sun J, Zhang H, Zhu HJ, Zhang YX, Zheng XJ, Zhou DZ, Hüttermann A, Chen SL (2010) Effects of stockosorb and luquasorb polymers on salt and drought tolerance of Populus popularis. Sci Hort 124:268-273

SMN Servicio Meteorológico Nacional (2008) Estadísticas Climatológicas 91-2000

Sojka RE, Bjornebergm DL, Entrym JA, Lentz RD, Ortsm WJ (2007) Polyacrylamide in agricultural and environmental land management. Adv Agron 92:75-162

Steiman SR, Bittenbender HC, Idol TW (2007) Analysis of kaolin particle film use and its application on coffee. Hort Sci 42:1605-1608 
Suarez ML, Germandi L, Kitzberger T (2004) Factors predisposing episodic drought-induced tree mortality in Nothofagus—site, climatic sensitivity and growth trends. J Ecol 92:954-966

Tejera L, Davel MM (2005) Establecimiento de pino oregón. Revista IDIA, INTA 8:97-100

Trillo N, Fernández RJ (2005) Wheat plant hydraulic properties under prolonged experimental drought: stronger decline in root-system conductance than in leaf area. Plant Soil 277:277-284

Vera-Castillo JAG (1995) The influence of antidesiccants on field performance and physiology of 2+ 0 ponderosa pine (Pinus ponderosa Dougl.) seedlings. Ph.D. Thesis, Oregon State University, pp 134

Villalba R, Veblen TT (1998) Influences of large-scale climatic variability on episodic mortality in northern Patagonia. Ecology 79:2624-2640

Wand SJE, Theron KI, Ackerman J, Marais SJS (2006) Harvest and post-harvest apple fruit quality following applications of kaolin particle film in South African orchards. Sci Hortic 107:271-276

Wilson J, Munro RC, Ingleby K, Mason PA, Jefwa J, Muthoka PN, Dick JMP, Leakey RRB (1991) Tree establishment in semi-arid lands of Kenya-role of mycorrhizal inoculation and water-retaining polymer. For Ecol Manag 45:153-163

Zar JH (1999) Biostatistical analysis, 4th edn. Prentice Hall, New Jersey 